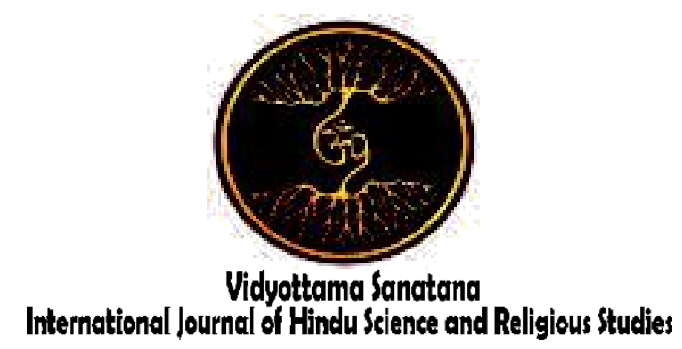

Vol. 2 No. 1 May 2018

\title{
Materialization And Humanization Of The Spirit: A Contextualization Based On The Stylistic Representation Of The Balinese Hindu Modern Philosophy
}

\author{
By: \\ W.A. Sindhu Gitananda1, I Wayan Cika ${ }^{2}$, I Nyoman Suarka ${ }^{3}$, I Wayan Suka Yasa ${ }^{4}$ \\ ${ }^{4}$ Universitas Hindu Indonesia, ${ }^{23}$ Universitas Udayana \\ E-mail: ${ }^{1}$ gitanandas@yahoo.com, ${ }^{2}$ cika.wayan@yahoo.com, ${ }^{3}$ tuarik4@yahoo.com, \\ ${ }^{4}$ iwayan_sukayasa@yahoo.com
}

Received: Desember 5, 2017

Accepted: May 3, 2018

Published: May 31, 2018

\begin{abstract}
The prominent characteristic of the pre-modern and modern philosophical discourse in the archipelago is generalized to that of the spiritualism with the saivistic discourse; including a Balinese modern philosophical text entitled Aji Sangkya. However, the title of the text shows diachronic relationship with the Samkhya Dharsana the so-called Indian (Hindu) materialism with its jargon 'evolution'. The tension between the discourse of spiritualism and materialism in the text is the main concern of the article based on its stylistic representations. The contextual stylistics and the deconstruction approach provide great opportunities to the Aji Sangkya to be interpreted as well as contextualized. Having elaborated the data, it is found that the text implies the process of materialization of the spirit (purusha or atman) into the circle of material (pradhana), until finally becoming material itself. Nonetheless, this materialization cannot merely be understood as the process with the ultimate goal of materialism, but implicitly of humanization since the human (manusa) comes as the ultimate accumulation of all the philosophical categories. The term related to the materialization must be taken as the process of humanization or making the spirit humanized; the humanism take the middle position between the spiritualism and the materialism in Aji Sangkya, the so-called Balinese Hindu modern text of philosophy.
\end{abstract}

Keywords: materialization, humanization, discourse, stylistics, Aji Sangkya, Balinese, philosophy 


\section{Introduction}

The philosophical texts (tattwa) in the archipelago, such as Wrhaspati Tattwa, Tattwa Jnana, Dharma Patanjala, and Aji Sangkya, since the postcolonial period have attracted the attention of researchers, especially philologists and indologists. Diachronic assessment, especially of the philological nature, becomes the focus for viewing the periodization of adaptation and the historicity of the text so that the authentic or the most ancient texts (arche writings) can be decided. In addition, the development of the text has also been studied as the representation of the culture in order to be more easily understood its roots, as often was conducted by Hooykaas formerly around the 1950s, especially to the Aji Sangkya. In addition, a similar study was conducted by Raghu Vira and Sudarshana Devi in 1957 to Wrhaspati Tattwa -the text which has a close intertextual relationship with the Aji Sangkya. Through these studies it was found that the Sanskrit vocabularies were widely used in the philosophical texts in the archipelago, but the spellings were not in accordance with the Sanskrit grammar -the use of the Sanskrit terms is the starting point for the categorization of texts mentioned above as tattwa texts, rather than tutur that contains heterogeneous compilation of writings (Acri, 2011: 10). There are also efforts to adjust or restore all aspects of the language in accordance with the Sanskrit grammar. Once the authenticity of the text can already be decided as authentic, the translation efforts by prioritizing formal or literal equivalent become the peak of the reviews.

Lately there has been little change in the pattern of the researchs. After the discovery of its authenticity, the text was adjusted to the spelling applicable to the study period, as what was done by Sukayasa and Jelantik (2008) to Aji Sangkya. In addition, the text is also analyzed interpretatively according to the patterns of understanding which can be viewed as contextualization according to the frame of understanding of the society in which the text is composed by its author, the frame of the Balinese Hindu understanding (including that of the Old Javanese). Thus it was found that the Aji Sangkya was constructed with a story-telling style, consisting ten parts within its structure, following the cause-and-effect logic framework of thinking, evolving from the most ignorant tattwa 'philosophical category' to the most secular -from the most gross to the finest layers. Then the layer after layer are peeled back as a teaching of deliverance (kaivalya) -which signifies pasuk-wetu 'in and out' mindset; out getting rougher, in getting smoother. Finally, the Aji Sangkya was concluded as a saivistic text.

Then Yasa (2010) conducted a study to the Tattwa Jnana -text which also has an intertextual relationship with the Aji Sangkya and the Wrhaspati Tattwa-to reveal the brahmawidya 'theology' implied within. Based on this study, it was concluded that the Tattwa Jnana was also theological text with the saivistic turn; Shiva as the theos who has three categories of consciousness (tattwa), namely paramasiwa tattwa as the transcendent consciousness, sadasiwa tattwa as the category of absolute consciousness, and atmika tattwa as the category of immanent consciousness. Nonetheless, there had been no explanation that the three categories stylistically mutually deconstructed one 
another; the presence of one tattwa to mean the absence of the two others.

A very comprehensive diachronic study was conducted by Acri (2011) to the Dharma Patanjala. This study encompasses or traces all the historical and the intertextual aspects of the Dharma Patanjala texts in the archipelago as well as its canonic discourse based on the Indian philosophical perspective of text, the Yogasutra of Patanjali (Acri, 2011: 96). Similar result was also found by Gitananda (2015) that the connection of the philosophical texts (read: Aji Sangkya, Wrhaspati Tattwa, and Tattwa Jnana) are very closely related to the texts of darsana from India, the so-called Hindu philosophy, especially to the Samkhya Karika and the Yogasutra -the terms used in the texts were still clearly legible in Sanskrit. Thus, the philosophical discourse in texts in the premodern up to the modern period in the archipelago can be understood to have very closely relation to the Indian (Hindu) philosophy.

However both studies still ignore the synchronic elaboration associated with the use of Balinese language combined with the terms derived from the Sanskrit language. One example, the word 'siwa', to be read /siws/ or /siwa/, written in Sanskrit 'śiva' and can be read /fiv-/, /fi: v-/, /si: v/, /sivə/. The change of phoneme may be taken as the way of the Balinese religiosity immediately has changed the imagery of the word; the image of Shiva has also changed in the Balinese theology. Moreover in the clause, "Siwa lawan Maya punika kaupamiang aji ring biang (Shiva and Maya is similarly like father and mother)"; the word 'siwa' has experienced adaptation and assimilation from the word 'siva'.
The Indian philosophy, in addition to empirical and intellectual, is mystical and spiritual (Zuhry, 2013: 4). The knowledge does not stop on the empirical or intellectual elaboration since both kinds of knowledge cannot explain the beyond, the abstract thought. Therefore all must lead to the spiritual knowledge. The spiritual knowledge referred to is the realization of the individual spirit that is micro (atman/ purusha or spirit/ soul), unchangeable, immortal and perennial (cf. Zimmer, 2003: 6). Through the realization of this individual spirit the universal spirit of the universe can be immediately understood. The spiritualism is the 'big umbrella' to understand the Indian philosophy which later might become the 'generalization' applied to the texts of philosophy (tattwa) found in the archipelago.

The article written by Acri in 2013 confirms that the Aji Sangkya reformed the saiva yoga discourse in the modern era understood from the Old Javanese texts (Acri, 2013). The term 'saiva yoga' was chosen because the spiritualistic orientation of the text leads to Shiva as the absolute consciousness (cetana) which then evolves undergoing materialization-into transcendent consciousness (parama shiva), to the immanent consciousness (siwatmal atmika). The Aji Sangkya was seen as a text of yoga because it had an intertextual relationship with the text of Yogasutra Patanjali originating from India. The text of Yogasutra Patanjali has more technical aims to guide the reader to reach the spiritual realm. Thus, the Aji Sangkya was also considered so. In fact, the term 'sangkya' (on the title) is more closely related to 'samkhya', which in six philosophical systems in India tends to have materialistic discourse, closely related to 
the term 'evolution'. This indicates that there is a tension of discourse between the spiritualism and the materialism within the text. The synchronic issue of the text, which is, taking into account of the use of its language, has never been discussed in depth through the point of view of discourse, especially focused on its language use, the stylistics. Therefore, it is important to study the use of language focused on the discourse where the tension between the spiritualism with the materialism in the Aji Sangkya to reveal the meaning of the tension.

\section{Methods}

The Aji Sangkya is a text distributed in the form of mimeographed pamphlet in 1947 by Ida Ktoet Djelantik (late 1961) under the title Adji Sankya. This text underwent translations and publications by various translators and publishers. Four years after the publication in the stencil print, the text was translated into Dutch by Hooykaas (1951) to be entitled Changkhya-leer van Bali in Tijdschrift voor Indische Taal-, Landen en Volkenkunde (Wisasmaya, 2012; Acri, 2013). Later, I Gde Sandhi (1972) translated it into Indonesian with the title of $A j i$ Sangkhya published by the Directorate General of Hindu and Buddhist Community Guidance in Jakarta. There is also a version in the form of lontar, in Balinese alphabet (aksara), found in Kasimpar, Abang, Karangasem under the title of Tutur Aji Sangkya which is then transliterated and stored in Pusdok Bali (T/I/12=K31, 60 folio pages). Then, in 2008 the Aji Sangkya became the object of philology study by I Wayan Sukayasa and Ida Bagus Jelantik published by Widya Dharma. The Aji Sangkya is the text in Balinese with old spellings which then was edited according to Balinese based on Indonesian formalized spelling, translated into Indonesian, and briefly analyzed -the results of this study are deemed very appropriate to be the primary data source in addition to the original text and the translation and taken as the corpus of language to understand the Balinese Hindu philosophy. There are also other translations into Indonesian, claimed to be done by Ida Ktoet Djelantik (the author of the original text) and edited by Ida Komang Wisasmaya (2012), published by Paramita Surabaya. Finally, the Aji Sangkya version of Sukayasa and Jelantik has again reprinted in Mabakti, Denpasar, lately.

In addition, the Aji Sangkya is a text that has both textual and intertextual dynamics. As described above, its intertextual dynamics has long attracted the attention of former researchers. However, the concerns to the textual dynamics that take the topic about the philosophical discourse are still minimally conducted. IBM Dharma Palguna (2015) made a testimony about the Aji Sangkya in the form of essay in the internet that this text has true and beautiful language, and it may be considered the door to enter the inner civilization of Bali. This testimony can be the lighter of passion and an opening to the synchronic understanding. For that, the contextual stylistics theory (Zyngier, 2001) was utilized to describe the phenomena of language use descriptively by considering all matters relating to the language of the Aji Sangkya. Furthermore, understanding is enhanced to the hermeneutical stage by utilizing deconstruction theory (in AlFayyadl, 2005 and Hardiman, 2015) so that the interpretation or the contextualisation can be carried out, for example through the use of 
more global term to describe the thought. This is due to the frequency of the philosophical discourse in the Aji Sangkya. The library research method with the close and critical reading technique was very appropriate for the sake of elaborating the main focus of discourse about the materializatin of spirit within the tension between the spiritualism and the materialism.

\section{Results And Discussion}

Translating and re-publishing the $A j i$ Sangkya were very serious ways of reception. This indicates that this text has given deep impression to its readers. Of course, through that ways, the Aji Sangkya has already been very widely read by many Eastern philosophical literature lovers. Nevertheless, the stylistic synchronic studies with the discourse perspectives have not been widely applied to the text.

The discourse coming to the surface in the first reading of course is the Saivistic term 'siwa' to be used in the text from the beginning. It is also explained in the introduction to the Aji Sangkya that the book is based on the teachings of igama Siwa (Djelantik, 1947: 1). The term 'igama' is often understood in terms of the nature of God and the interconnection of man with God (Arista, 2017: 36; Bhakti, 2015). In addition, in a blog it is written that this term means philosophy, the deepest inner attitude, or outlook on life (http://cakepane.blogspot.co.id/2014/09/igam a-agama-dan-ugama.html: 2014). This last explanation is also closely related to Palguna's testimony (2015) as explained in the introduction that the Aji Sangkya is the door way to entering the inner civilization of Bali. The diagram presented below may figurize the structure of understanding of the philosophical discourse in Aji Sangkya.

Figure 1. Structure of the evolution of the philosophical discourse in the Aji Sangkya

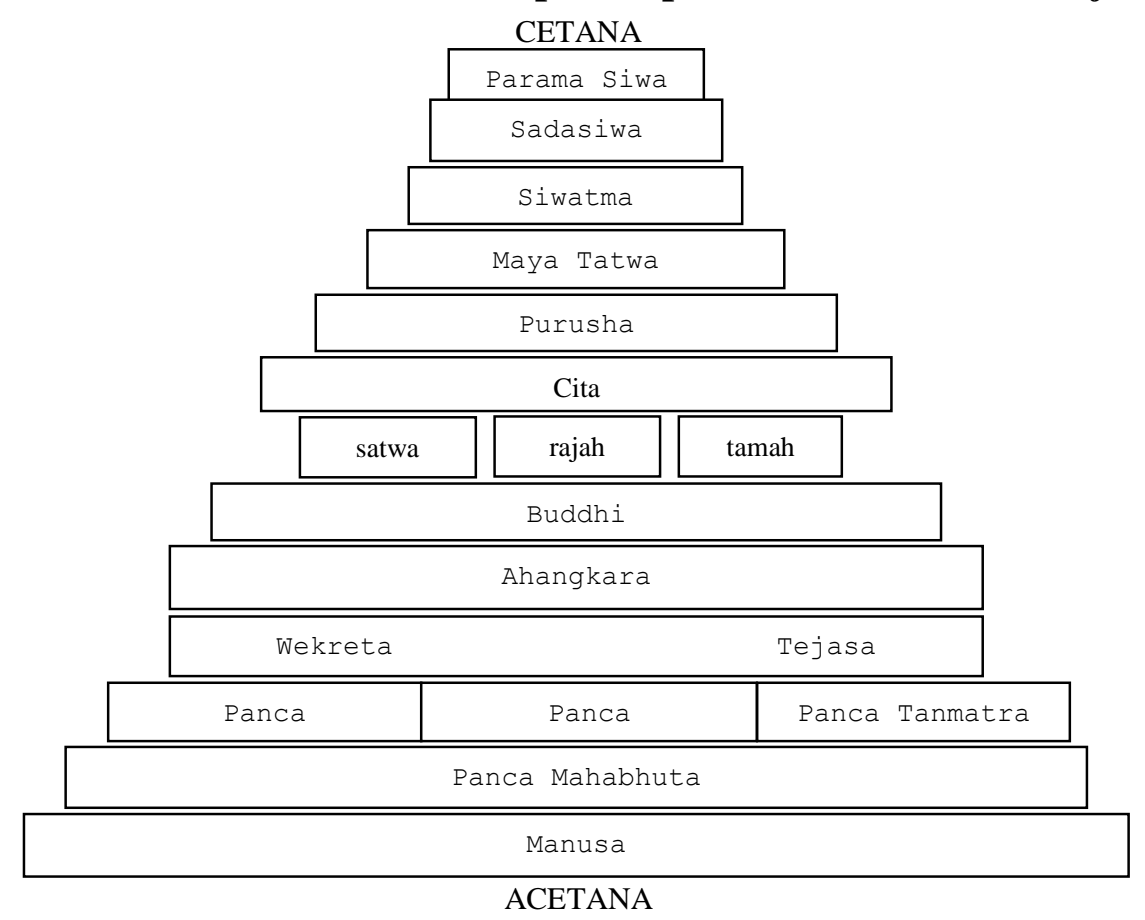


3.1 Cetana Versus Acetana: the Source of Spiritualism (Siwa Tattwa) Versus the Source of Materialism (Maya Tattwa)

The saivism or siwa tattwa has become the principle of the spirituality in the Aji Sangkya. The word 'spirit' means breath, life, soul, and mind. Then, the spiritualism is the doctrine that mentions the spirit as the highest substance of the world (cf. Blackburn, 2015: 830), which in this case is oriented towards Shiva. Based on the Aji Sangkya, the main principle of the spirit is called 'cetana' which means 'conscious'. That conscious is Shiva, the true cetana. The opposite is 'acetana' or 'unconscious' (Djelantik, 1947; Sukayasa, 2008: 15). The acetana is the principle for understanding materialism in the Aji Sangkya. This thought holds that the world is completely conceived by the materials (Blackburn, 2015: 538). The following quotation can explain the relationship of both.

(1) Cetana ring acetana punika kawentenan kalih ungguhnya mapapas: Cetana rumaga ening bresih, pradnyan menget tan kahanan lupa, eling kenceng tan patanggu, punika mungguh ring luhur. Acetana punika sane mungguh ring sor, rumaga lupa tan kahanan menget, kadi batu celebungkah saluiripun. Diastu pateh antuk suksma kaluihan Ida, kalih sami luputing suka duka, kewanten antuk Cetana punika ngranjing nyusup mamedah nguub tattwane ring sor sane kabaos Acetana, tatwane ring sor tan sida ngaranjingin tatwane ring luhur, punika kabaos utamayan ugi tatwane ring luhur (Sukayasa and Jelantik, 2008:15)
Cetana and Acetana are opposed to one another. The cetana is clear, silent, intelligent, always remember and never forget, always aware continuously, which takes place above of the other. Meanwhile, the acetana takes the below position. It will always forget, never aware. Its is like a rock or a stone and the like. Despite having the same virtue, both escape from grief, but because the cetana infiltrates, enters, penetrates, encompasses the principle beneath the so-called the acetana, while the beneath principle cannot enter the aforesaid principle, the above principle may be taken to be more important.

The citation from the corpus above shows that from the beginning there has been a tension between the two principles: the spiritualism and the materialism. In other words, there has been a dualism between them represented by the phrase "ungguhnya mapapas (opposite position)", indicating the contradictory nature of both. Then, the contradictory nature is treated and embodied as follows.

(2) Cetana miwah Acetana punika sane kabaos Siwa Tatwa lawan Maya Tatwa (Sukayasa and Jelantik, 2008:15).

Cetana and Acetana are the so-called Siwa Tatwa and Maya Tatwa.

The above quotation confirms that the cetana is the siwa tatwa and the acetana is the maya tatwa. Furthermore, the siwa tattwa is then divided into three: paramasiwa tattwa, sadasiwa tatwa, and siwatma tatwa. The characteristic of these three kinds of siwa is shown by the use of the word 'menget', which 
comes from the word 'inget' which means to remember or to be conscious with the prefix /ma-/ --vowel sound/a/ in the prefix [ma-] and /i/ in [inget] are undergoing vocal mixing (Schane, 1992: 57) or called "sandi suara" (Warna, 1990: vi) becomes /é/ so [ma-inget] becomes /ménget/. The prefix [ma-] means having, containing, or equal to prefix [ber-] in Indonesian. Thus, 'menget' means to remember, to have memory, or to be conscious.

\subsection{Hierarchy of the Spirit: Paramasiwa, Sadasiwa, and Siwatma}

The three derivatives of the siwa tattwa (spirit or consciousness) discussed earlier can be distinguished by their quality of menget. The difference of the three shows their position in the hierarchy: the paramasiwa is the highest, the sadasiwa is below it, and the siwatma is at the bottom under the sadasiwa. All three become the principles of the spiritual level in the Aji Sangkya. The following table can show the consciousness hierarchy.

Table 1

Hierarchy of Consciousness based on the Stylistic Representation

\begin{tabular}{|c|c|}
\hline & \\
\hline $\begin{array}{l}\text { Menget sane kapretama, } \\
\text { binih luhur miwah pinih } \\
\text { utama. Punika sane sujati } \\
\text { ening bresih, antuke tan } \\
\text { kawaranan antuk punapa- } \\
\text { punapi. Langgeng Ida antuke } \\
\text { an wenten kaobahan, tan } \\
\text { wenten lekad, tua, mati. Tan } \\
\text { venten sane riin, mangkin } \\
\text { miwah kapungkur. Degdeg } \\
\text { antuke tan molah. Boya } \\
\text { tglencok. Boya membah } \\
\text { kalih tan wenten mamargi. } \\
\text { Boya sabda, boya sparsa, } \\
\text { boya rupa, boya rasa kalih }\end{array}$ & 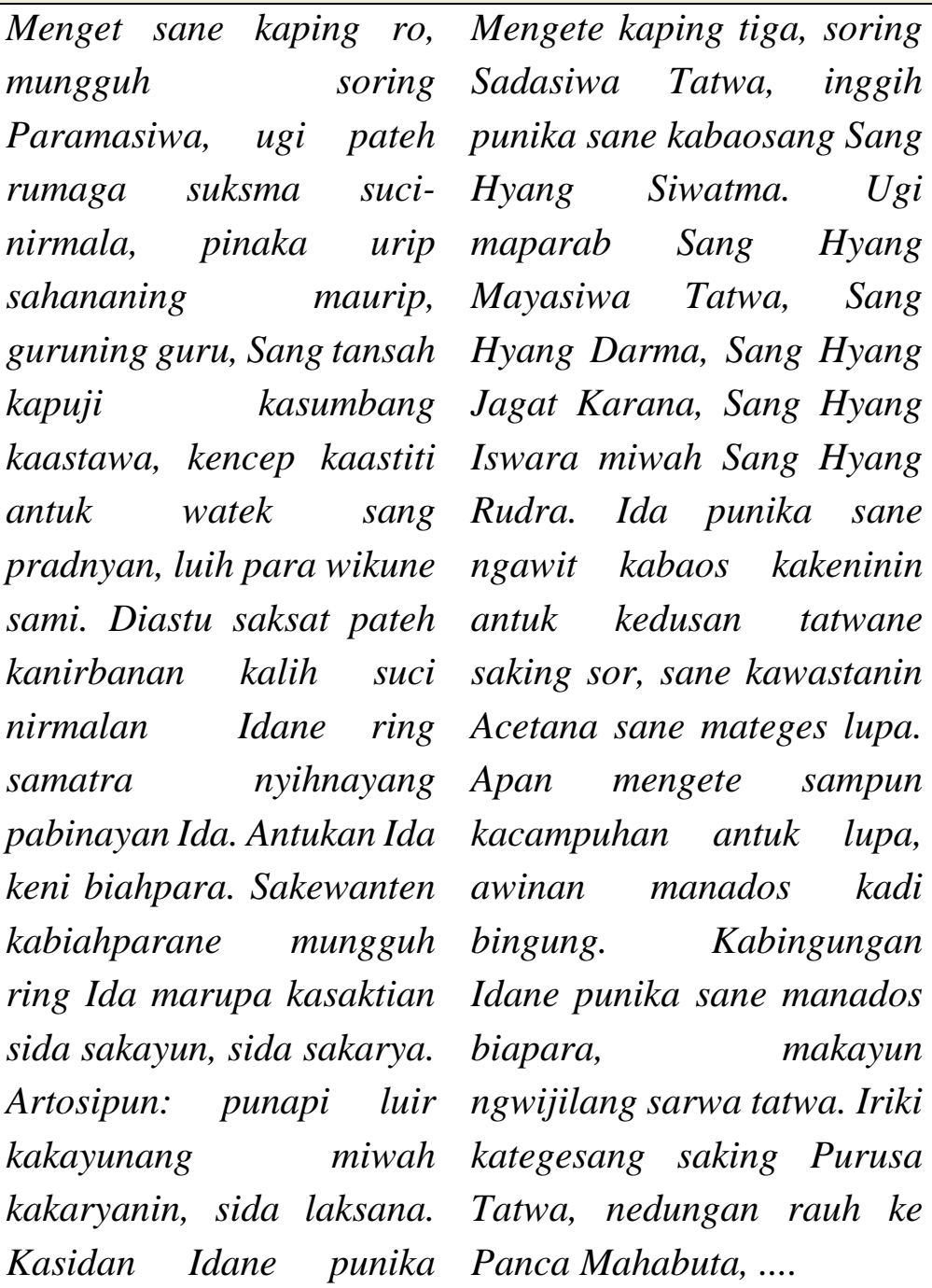 \\
\hline
\end{tabular}




\begin{tabular}{|c|c|c|}
\hline & $\begin{array}{l}\text { kawastanin Padmasana. } \\
\text { Yan tegesang, rupa tampek } \\
\text { artosipun ring dedampar } \\
\text { tanjung. Dados, dedampar } \\
\text { malakar utamawi mapinda } \\
\text { tunjung. }\end{array}$ & \\
\hline $\begin{array}{l}\text { Paramasiwa is the first } \\
\text { consciousness, the most } \\
\text { noble and most important. } \\
\text { This real awareness is silent } \\
\text { because it is not polluted by } \\
\text { anything. He is permanent } \\
\text { because there is no change. It } \\
\text { has no born, old, and dead. } \\
\text { Nothing ago, now, and then, } \\
\text { very calm down because it } \\
\text { has no movement; no wavy, } \\
\text { no flow and no walking. It is } \\
\text { not a word (sound), not a } \\
\text { touch, not an image, not a } \\
\text { taste, not a smell, and not } \\
\text { something to consider } \\
\text { because we cannot hear, feel, } \\
\text { see, smell, and think. It is } \\
\text { perfect because it has no } \\
\text { limitations; no disease and no } \\
\text { old age. }\end{array}$ & $\begin{array}{l}\text { Sadasiwa is the second } \\
\text { consciousness, which takes } \\
\text { under the Paramasiwa. } \\
\text { Having similar (quality), it } \\
\text { is unseen, sacred, and pure. } \\
\text { It is the life of life, teacher } \\
\text { of teacher. It is always } \\
\text { praised, glorified, upheld, } \\
\text { and contemplated by the } \\
\text { thinkers and the clergy. } \\
\text { Though it is having equal } \\
\text { quality of voidness, purity, } \\
\text { stainless with the so-called } \\
\text { first consciousness, but } \\
\text { there is also little } \\
\text { difference. Because it starts } \\
\text { to have activity. But the } \\
\text { form of activities exists in } \\
\text { the form of supernatural } \\
\text { powers: achieve all his will, } \\
\text { succeed all his works. } \\
\text { Meaning: everything that is } \\
\text { desired and conducted } \\
\text { immediately becomes true. } \\
\text { Its success is called } \\
\text { Padmasana. If understood, } \\
\text { it is something similar to } \\
\text { the lotus seat. So, the seat is } \\
\text { made or in the form of a } \\
\text { lotus. }\end{array}$ & $\begin{array}{l}\text { The third consciousness } \\
\text { under the Sadasiwa is called } \\
\text { Sang Hyang Siwatma. It is } \\
\text { also called Sang Hyang } \\
\text { Maya Sira Tatwa, Sang } \\
\text { Hyang Dharma, Sang Hyang } \\
\text { Jagatkarana, Sang Hyang } \\
\text { Iswara, and Sang Hyang } \\
\text { Rudra. It is the one which is } \\
\text { affected by the principle } \\
\text { from below, the acetana, } \\
\text { which has the quality of } \\
\text { forgetting. Since this } \\
\text { consciousness has been } \\
\text { blanketed by forgetfulness, it } \\
\text { becomes confused. The } \\
\text { confusion is what makes it } \\
\text { has activity to create sarwa } \\
\text { tatwa. Sarwa tatwa refers to } \\
\text { the tattwa from purusa tatwa } \\
\text { to panca mahabhuta tatwa, } \\
\text {... }\end{array}$ \\
\hline
\end{tabular}

Source: Sukayasa and Jelantik (2008:16 - 21) (adapted from Djelantik 1947)

The data taken from the corpus of the Aji Sangkya in the table shows clearly the three hierarchical positions that the paramasiwa is "menget sane kapretama (the first consciousness)", the sadasiwa is "mengete sane kaping ro (the second 
consciousness)", the siwatma is "mengete kaping tiga (the third consciousness)". Stylistically, the characteristic of the paramasiwa is expressed by the use of the (negative) word 'tan (no)' and the phrase 'tan wenten (not; no; never; nothing)' as in 'tan kawaranan punapa punapi (not polluted by anything)"; "tan wenten kaobahan (never change)"; "tan wenten lekad, tua, mati (not born, old and dead)"; "tan wenten sane riin, mangkin miwah kapungkur (not in the past, the present, and then (future))".

Furthermore, the more obvious is the use of the word 'boya (not)'. It is synonymous meaning with the word 'tan'. The use of this word may be observed in the phrase "boya nglencok (not wavy)"; "boya membah (not flowing)"; "boya mamargi (not walking; not running)". Then in other phrases, it presents as "boya sabda (not word; not sound)", "boya sparsa (not touch)", "boya rupa (not form or image)", "boya rasa (not taste)", and "boya ganda (not smell)". This state of mindfulness can be synonymous with the nihilism or the consciousness of denying (cf. Blackburn, 2013: 604). All things related to the materialism are rejected, negated.

The paramasiwa tattwa is the category of philosophy that is really difficult to explain in the text, the strategy is only by using the negative word 'tan' and 'boya'. This may be taken the peak of spirituality that can be understood in the Aji Sangkya. The true spirit is understood as nothingness; there is absolute truth because it cannot be explain by words. Therefore, the consciousness must be degraded into the more personal, God, the sadasiwa, in order to 'consider' the inconsiderable, to 'learn' the unlearnable, and to 'perceive' the unperceivable (cf. Acri, 2011:355).
Sadasiwa tattwa has the character that may be regarded as a divine consciousness, absolute consciousness or as God of religions. This is indicated by the use of the suffix [ning], the allomorph of [-ing], to denote the words hierarchy; the first word has higher, even the highest (greatest), hierarchical position then the next. This affix has a similar function with prefix [ $d i-]$ in Indonesian like in "raja diraja (the king of kings; the greatest king)" or preposition [of] in English, for example in "guruning guru (the teacher of all teachers)".

The suffix [-ning] has similar meaning semantically with the word sahananing (of all; omni)' as in the phrase "pinaka urip sahananing urip (as the life of all lives)". Similarly, the use of the word 'sida (achieved, succeeded, or successful)' also implies similar meaning as found in this expression, "Sakewanten kabiahparane mungguh ring Ida marupa kasaktian sida sakayun, sida sakarya (However the activities exist in the form of supernatural powers: achieve all his will, succeed all his works)". This can mean that the sadasiwa is the really absolute consciousness, the all successful.

Then, the comparison is made with the word 'padmasana'. It may be defined as the lotus seat (Sukayasa and Jelantik, 2008:79) to assume all wills may surely be achieved (cf. Dwijendra, 2013). This is the consciousness that has the supernatural power. It has many activities which are successful. In the clause, "Sakewanten kabiahparane mungguh ring Ida marupa kasaktian.... (However the activities come to $\mathrm{Him}$ in the form of supernatural powers....)". The supernatural powers are of four, called cadusakti (four power): dnyana (jnana) sakti 'knowledge', wibhu sakti 'pervasion', prabhu sakti 
'sovereignity', and kriya sakti 'action' (cf. Acri, 2011:357). Because all the powers are possessed, the sadasiwa can be regarded as the consciousness of "I", the center or the first singular subject. The centeredness exists in this hierarchical level of consciousness, which is truly absolute.

The third is the siwatma which is positioned under the sadasiwa. There are many names or terms that can represent this level of consciousness, such as the hyang siwatma, the hyang mayasira tatwa, the hyang darma, the hyang jagat karana, the hyang iswara, and the hyang rudra. If so, this consciousness is equivalent to the consciousness of the gods, since the word 'gods' has a mutually substituted meaning with the word 'hyang' (Mardiwarsito, 1990:229; Warna, 1990:256). Through these substitutions of name here it can be understood that 'siwatma' is an immanent consciousness. In this position, the siwatma is the materialistic consciousness when it is synonymized with the term 'mayasira (materialistic consciousness)' if it is also called the hyang mayasira tatwa (see MonierWilliams, 1999: 811).

As shown in table 1 above, the sentence related to the siwatma, "Ida punika sane ngawit kabaos kakeninin antuk kedusan tatwane saking sor, sane kawastanin Acetana sane mateges lupa (It (the consciousness) is mentioned to have irritation from the bottom tattwa, which is called the acetana, in which the unconsciousness exists)" (Sukayasa and Jelantik, 2008:21). This shows the hierarchical position under the sadasiwa. This consciousness is also said to have been covered by the forgotteness, then experiencing confusion, undergoing forgetfulness. The spirit has undergone 'fallenness' into unconsciousness. In other words, the siwatma is the spirit (siwa) that has undergone materialization, therefore it becomes materialistic. The "I" that the sadasiwa has come to the state of I-lessness because it has been influenced by 'the other', the material (cf. Regan, 2012:289). This means, after that, 'the other' exists within the spirit; the siwa tattwa does not exist in its pure transcendent state as well as in the absolute state anymore.

\subsection{Materialized Spirit (Purusa) and Spiritualized Material (Predana)}

The hierarchical level of spirit as explained above has given contextualized understanding that the consciousness is not always in its firm state. It is very dynamics based on its stylistic representation in the corpus. The pure transcendent position should always fall into the downer position: the 'tan' or 'boya' (nihilism) falls into the '-ning' or 'ing' (sida) position and then continues to the 'hyang'. These three states overcome one another; the presence of one state means the absence of the others. Through this hierarchy the Balinese modern philosophical discourse that implies the inner civilization in Bali may be understood as well.

After that, in order to have the understandable state of the spirit (siwa), the word 'purusa' comes to deconstruct all the state of the spirit. Here, it is called 'purusa tatwa'. This is where the tension between the discourse of spiritualism and materialism comes over because by only mentioning "purusa" already signifies the presence of "predana" in the corpus of the Aji Sangkya. The following table can explain the understanding and the relationship between the two. 
Table 2

Understanding and Relationship of the Purusa and the Predana

Purusa
Siwa lawan Maya punika kaupamiang aji
ring biang. Putran Idane puniki Sang
Hyang Purusa Tatwa. Banget ngambil
kamengetan aji. Sakewanten riantukan
bibite sampun kaworan lupa, sakirang-
kirangipun sampun taler pakirang
kamengetan Idane, yan bandingang ring
sang aji (Ida Sang Hyang Siwa) jantos
mengetang utawi mawuwuh kabiaparan
Idane. Rupan pawuwuh kabiaparan Sang
Hyang Purusa Tatwa madewek wisaya
weruh. Dados, Ida madue wisaya weruh
utawi seneng weruh.
Kasinahanipun, Ida Sang Hyang Purusa
Tatwa seneng uning ring sahanan sane
wenten, sakadi jagat rauh sadagingipun.
Kadi panyingakane sane madue wisaya
seneng nyingakin sahanan marupa, kadi
kayune seneng mikayunin, kadi suryane
seneng nyunarin, asapunika waluya Ida
Sang Hyang Purusa Tatwa, meweh yan
makarya tan weruh. Cutetipun uninge
punika, wisayaning purusa. Kinucap
pamargin bayune iriki ngulah munggah.
Predana

Predana Tatwa sane banget ngambilin lupaning Maya Tatwa sane maka ibu. Mawinan ugi Predana Tatwa punika manggeh maraga lupa. Punapa-punapi sane madewek lupa, sinah tan kahanan weruh. Punika duaning Predana Tatwa punika boya sane uning. Wantah sane kauningin antuk Purusa Tatwa. Pidaging, punapi sane kawikanin antuk Purusa Tatwa punika sane mawasta Predana Tatwa.

Diastu Purusa Tatwa punika taler ngibek wredi amenuhi buana, nanging asapunika ugi Predana Tatwane ngibek ring jagate.

Sang Purusa ngawrediang urip. Sang Predana taler tan katunan manglimbakang angga maka wadah. Sang Purusa ngalimbakang uning, Sang Predana ugi tan pegat ngawrediang sane kauningin. Cutetipun Predana Tatwa punika, diastu maparindikan tungkas, nanging pamuputipun matemu, apan saling dudut. Tan gampang pacang nginasang, antukan jagate puniki sami rauh sadangipun mawangun saking Predana Purusa. Nenten wenten punapa punapi ring jagate sane tan madaging Predana Purusa. Apan mawiwit Predana Purusa, mawinan sami awaking Predana Purusa

Siwa and Maya are like father and mother. Predana Tatwa takes over the forgotten His son is Sang Hyang Purusa Tatwa. He nature of the Maya Tatwa, her mother. took a lot of consciousness of his father. Therefore the Predana Tatwa also remains However, because the seeds are tangibly forgetting. Everything that tangibly contaminated, at least the consciousness has diminished, when compared to the father (Sang Hyang Siwa), having the greater or increased activities. In addition to the Purusa Tatwa. That is, everything that is 
activities of the Sang Hyang Purusa Tatwa is in the form of curious. So he has a curious or knowing nature.

Clearly, the Sang Hyang Purusa Tatwa is happy to know everything that exists, like nature and everything in it. Just as the eye has the pleasure of seeing everything out of it, as the mind likes to think, as the Sun likes to shine, so as the Sang Hyang Purusa Tatwa. It's hard to make him do not know. Knowing is the nature of the Purusa. It is explained that the motion of bayu, the energy, here tends to increase. known by the Purusa Tatwa is called the Predana Tatwa.

Although the Purusa Tatwa is fulfilling the universe, the Predana Tatwa is contained in all. The Purusa delivers life, the Predana no less delivers the body as the container. The Purusa delivers knowledge, the Predana does not stop unleashing the known. In short, although the Predana Tatwa is his opposition, but in the end it meets together because both are mutually attractive one another. It is not easy to separate it, because this universe and all in it are built of the Purusa-Predana. There is nothing in this universe nature that does not contain the Predana Purusa. Because it comes from the Predana Purusa, then all is the embodiment of the Predana Purusa.

Source: Sukayasa and Jelantik (2008:22—23) (adapted from Djelantik 1947)

The Purusa, as described in the corpus, is the spirit that cannot be separated from the material; its presence means the absence of all previous states of spirit. The state of the purusa is different from the siwatma explained above it, not the spirit, but the soul. This word may not be separately mentioned with its pair, the predana or the body. There must be the soul if there is the body, so as conversely.

In order to make it clearer, there are utilizations of simile style through the word 'kaupamiang' in 'Siwa lawan Maya punika kaupamiang aji ring biang ("The Siwa and the Maya is like father and mother)." The composition of the word /upami/ with prefix /ka-/ and suffix /-ang/ to mean like, as, for example, suppose, supposing that, and so forth, opens the path of understanding to the next elaboration. The simile of the siwa with $a j i$ 'father' and the maya with $i b u$ 'mother' is a personification strategy (cf. Damono, 2014: 43). The use of the word 'sakadi' and 'kadi', the word 'waluya' as well in the corpus also implies similar personification and comparison with the next words. To have simpler way of understanding, the personification is really effective though there are few contradictions with the earlier understanding.

The use of language in this context is also applied to the predana tatwa. This category is expressed using the word 'maraga' and 'madewek' to have the meaning of embodying. The words 'angga' and 'wadah' also imply similar sense as body, cover, container, and so on. The predana is said to be the body of the purusa, the soul. This use of words again deconstructs all other categories of philosophy coming earlier; the 
spiritual words are accumulated in the purusa and the material words are accumulated in the predana. The soul and the body must meet together. In this manner, the words that imply spirituality are "demoted" and the words implying materiality are "promoted".

\subsection{Manusa: the Meeting Point of the Spirit and the Material}

The demotion of spirit and the promotion of material must meet at a certain point. In the corpus of the Aji Sangkya, this point is called 'manusa (human being)'. In the last discourse, the meeting of the purusa (the accumulation of spirits, the consciousness) and the predana (the accumulation of materials, the unconsciousness) is the 'manusa', the human being. As earlier explained, the human personality traits cannot be avoided in the understanding of the word 'siwa (consciousness or spirit)' and 'maya (unconsciousness or material) that have been originally established in a more abstract understanding.

The tattwas 'categories of philosophy' can be said to deconstruct one another; the distinction of a category means the delay of meaning of another or the presence of one means the absence of the other (cf. the différance concept of Derrida in Hardiman, 2015:288). The deconstruction referred to is to mean humanization or humanity has been applied to the spirit and material. That is, all of which are originally spirit or abstract (consciousness) then "earthed" or materialized, then on the contrary, everything that is originally material experiencing spiritualization; the spirit is manifested by the material, which is then evolved by the spirit (into all categories of philosophy (sarwa tatwa) until accumulated into human being) (cf. Burckhardt, "spiritual individual" in Tjaya (2004: 19). By the emergence of 'manusa' as the last philosophical category (tattwa) in the hierarchy of the philosophical discourse understanding in the corpus of the Aji Sangkya, all are simpler to understand. The following quotation may be the argument to explain the earlier understandings.

(3) Ring ajeng sampun kasinahang, Hyang Pretiwi punika pakumpulan sarwa tatwa. Artosipun Sang Hyang Cetana rauhing Purusa Tatwa, nglantur ring indria, manah miwah panca tanmatra, punika sami wenten ring Pretiwi. Raris sane mangkin sarining jagat punika sadrasa minakadinipun, punika matemahan manusa. Kengin ipun sampun sinah, imanusa dados pamuput pepupulaning sarwa tatwa (Sukayasa and Jelantik, 2008:62).

In the beginning has been explained, Hyang Pretiwi (Earth) is the gathering place of all tatwa. That is, Sang Hyang Cetana, also Purusa Tatwa, continues with the indria (empirical abilities; dasendria 'ten empirical abilities), manah (mind) and panca tanmatra (five subtle elements), all of them are in the pretiwi (Earth). Then the essence of the universe (called) sadrasa (six flavors) and all its understanding are manifested or transformed into human. Thus it is clear that the human being becomes the ultimate accumulation of the sarwa tatwa.

Based on the quotation above it is explicitly stated that 'Hyang Pretiwi' (the honorable name for the Earth) is where the sarwa tatwa 'all categories of philosophy' are gathered. The sarwa tatwa is aligned with 
'sarining jagat (the essence of the universe)'. That is to say, the pretiwi 'Earth' is similarized with the manusa 'human', especially through the affirmation using the last sentence, "Kengin ipun sampun sinah, imanusa dados pepulaning sarwa tatwa (Thus it is clear that the human being also become the ultimate accumulation of the sarwa tatwa) (Sukayasa and Jelantik, 2008:62)." In other words, the human (located on Earth) is the ultimate accumulation of all philosophical categories, the spiritualism and the materialism (cf. Mirandola in Sugiharto, 2008: xvii.) Based on that understanding, the human may be understood to be not fully spirit or not fully material, he is in between the tension of both. Moreover, the human who has this state of understanding can be compared with the term 'Dasein' to call the 'existentialist man' in Heideggerian philosophy (see Hardiman 2003, 2015: 112) or the Übermensch in the Nietzschean philosophy (see Wibowo (ed.), 2009:31). Therefore, the discourse of humanism has deconstructed other discourses within the corpus of Aji Sangkya, taking the in-between position of the tension between the spiritualism and the materialism.

Here, in the Aji Sangkya, the transcendental meaning of philosophy is released, and then the rests is the word plays, the specific stylistics of the text (Hakim in Wibowo (ed.), 2009:114). This is the socalled contextualization, where the use of the language is not other than making the text understandable and the reader reaches the understanding.

\section{Conclusion}

Based on a descriptive understanding, the use of language in the corpus of $\mathrm{Aji}$
Sangkya is then contextualized to the interpretative understanding by applying the deconstruction approach. It can be understood that there has been a tension between the spiritualism and the materialism within the discourse of philosophy. The tension is a tugof-war between the two primarily discourses through the use of the word 'cetana (conscious)' and 'acetana (consciousness)', 'siwa tattwa (consciousness or spirit)' and 'maya tattwa (unconsciousness or material), and 'purusa (soul)' and 'predana (body)'. The distinction is shown by the use of the word 'menget (level of consciousness)'. All these categories of philosophy are accumulated into the use of the term 'manusa (human being)'. In other words, there has been a process of humanization (humanity) of spirit and the humanization (humanity) through the materialization of the spirit that raises the discourse of humanism. Therefore, the human presence has deconstructed all discourses built with the use of beautiful language or word plays (stylistic representation) in the Aji Sangkya. The human being is the ultimate accumulation of all the tattwas. This is the inner civilization of Bali, the civilization of humanism.

\section{References}

Acri, Andrea. 2011. Dharma Patanjala: A Saiva Scripture from Ancient Java. Amsterdam: Egbert Forsten, Groningen, The Netherlands.

Acri, Andrea. 2013. "Modern Hindu Intellectuals and Ancient Texts: Reforming Saiva Yoga in Bali". Article in Bijdragen tot de Taal-, Land-en Volkenkunde 169. Brill.com/bki.

Al-Fayaddl, Muhammad. 2005. Derrida. Yogyakarta: LKiS. 
Arista, I Made. 2017. "Agama, Igama, Ugama." Wartam, edisi 29/Th. 3/Juli 2017.

Bhakti, Pramukti Adhi. 2015. "Igama, Agama, dan Ugama." https://pramredesign.wordpress.com /2015/01/13/igama-agama-ugama/.

Blackburn, Simon. 2013. Kamus Filsafat. Yudi Santoso (Penerj.). Yogyakarta: Pustaka Pelajar.

Damono, Sapardi Djoko. 2014. Bilang Begini, Maksudnya Begitu. Jakarta: Gramedia Pustaka Utama.

Djelantik, Ida Ktoet. 1947. Adji Sankya. Tanpa Penerbit.

Dwijendra, Ngakan Ketut Acwin. 2013. "Padmasana" Bangunan Suci Hindu, Sthana Tuhan Yang Maha Esa, Simbolis Alam Semesta". Artikel in Journal of Ipteks STD Bali Volume 1 Nomor 1 November 2013. Denpasar: STD Bali

Gitananda, W. A. Sindhu. 2015. Terminologi dalam Aji Sangkya: Studi Semiotik. Prosiding Seminar Nasional Bahasa Ibu VIII 2015. Denpasar: Program Studi Magister dan Doktor Linguistik associated with Program Pascasarjana FSB UNUD and Asosiasi Peneliti Bahasa-Bahasa Lokal.

Hardiman, F. Budi. 2003. Heidegger dan Mistik Keseharian: Suatu Pengantar Menuju Sein und Zeit. Jakarta: Kepustakaan Populer Gramedia associated with Pusat Penelitan STF Driyarkara.

Hardiman, F. Budi. 2015. Seni Memahami: Hermeneutik dari Schleiermacher sampai Derrida. Yogyakarta: Kanisius. http://cakepane.blogspot.co.id/2014/09/igam a-agama-dan-ugama.html: 2014.

Mardiwarsito, L. 1990. Kamus Jawa KunaIndonesia. Flores - NTT: Nusa Indah. Monier-Williams, Sir Monier. 1999. SanskritEnglish Dictionary. Delhi: Motilal Banarsidass Publishers Limited.

Nida, Eugene A. dan Charles R. Taber. 1974. The Theory and Practice of Translation. Netherlands: E.J. Brill, Leiden.

Palguna, IBM Dharma. 2015. "Aji Sangkhya dan Ida Ketut Jelantik". http://bukuspiritual.blogspot.co.id/20 $\underline{\text { 15/05/aji-sangkhya-dan-ida-ketut- }}$ jelantik-html.

Regan, Paul. 2012. 'Hans-Georg Gadamer's Philosophical Hermeneutics: Concepts of Reading, Understanding, and Interpretation." Article in Journal of Meta: Research in Hermeneutics, Phenomenology, and Practical Philosophy Vol. IV, No. 2/ December 2012: 2067-3655.

Sandhi, Gde. 1973. Aji Sangkhya. Denpasar: Ditjen Bimas Hindu dan Buddha.

Schane, Sanford A. 1992. Fonologi Generatif. Jakarta: Summer Institute of Linguistics.

Sudarsana, I. K. (2017). Konsep Pelestarian Lingkungan Dalam Upacara Tumpek Wariga Sebagai Media Pendidikan Bagi Masyarakat Hindu Bali. Religious: Jurnal Studi AgamaAgama dan Lintas Budaya, 2(1), 1-7. Sudiani, N. N. (2017). Pedanda Baka Story As Media Of Character Education Since Early Childhood. Vidyottama Sanatana: International Journal of Hindu Science and Religious Studies, 1(1), 61-68. 
Sugiharta, I. P. S. O., \& Sudarsana, I. K. (2017). Hypnotic Learning Characteristics On Sisya Brahmakunta Community In Denpasar. Vidyottama Sanatana: International Journal of Hindu Science and Religious Studies, 1(2), 132-145.

Sugiharto, Bambang (ed.). 2008. Humanisme dan Humaniora: Relevansinya bagi Pendidikan. Yogyakarta: Jalasutra.

Sukayasa, I Wayan dan Ida Bagus Jelantik. 2008. Aji Sangkya: Suntingan Teks, Terjemahan, dan Analisis Isi. Denpasar: Widya Dharma.

Ratna, I Nyoman Kutha. 2009. Stilistika: Kajian Puitika Bahasa, Sastra, dan Budaya. Yogyakarta: Pustaka Pelajar. Tjaya, Thomas Hidya. 2004. Humanisme dan Skolastisisme: Sebuah Debat. Yogyakarta: Kanisius.

Vira, Raghu dan Sudarshana Devi. 1957. Wrhaspati-Tattwa: An Old Javanese Philosophical Text. India: International Academy of Indian Culture.

Warna, I Wayan dkk. 1990. Kamus Bali Indonesia. Bali: Dinas Pendidikan Dasar Provinsi Dati I.

Wamaungo, J. A. (2017). Character Education Across Cultures: How Uganda Develops Students Desired Characters In Inclusive Perspective. Vidyottama Sanatana: International Journal of Hindu Science and Religious Studies, 1(1), 14-20.

Wibowo, A. Setyo et al. Para Pembunuh Tuhan. Yogyakarta: Kanisius.

Wisasmaya, Ida Komang (ed.). 2012. Kitab Aji Sangkya 1947. Surabaya: Paramitha.
Yasa, I Wayan Suka. 2009. Brahmawidya Teks Tattwa Jnana. Denpasar: Lembaga Penelitian associated with Fakultas Ilmu Agama Universitas Hindu Indonesia.

Zimmer, Heinrich. 2003. Sejarah Filsafat India. Yogyakarta: Pustaka Pelajar. Zuhry, Ach. Dhofir. 2013. Filsafat Timur: Sebuah Pergulatan Menuju Manusia Paripurna. Malang: Madani.

Zyngier, Sonia. 2001. "Towards A Cultural A Cultural Approach to Stylistics." Article in CAUCE: Revista de Filologia y su Didactica, Num 24. Brazil: Universidade Federal do Rio de Janeiro. 